\title{
TENDENCIES IN THE DEVELOPMENT OF SCHOOL PHYSICAL EDUCATION IN BULGARIA, MACEDONIA AND SLOVENIA
}

\author{
Eleonora Mileva, Ilija Klincarov, Biljana Popeska, \\ Marjeta Kovac, Gregor Starc
}

\begin{abstract}
Physical education is an integral part of the educational system. In the EU Work Plan for Sport 2014-17 it is emphasized that physical education teachers are key agents for putting physical and sport policies into practice. The aim of the research is to study main elements of the physical education systems in three Balkan countries - Bulgaria, Macedonia and Slovenia. The following criteria are outlined: status of physical education in the educational system; learning programs; professional qualification of teachers; buildings and facilities for physical education classes. The research methods that have been used include a study of educational documentation, analysis of specialized literature sources, and comparative analysis. In the three countries of the research, physical education is an obligatory school subject in all levels of their education systems. In Bulgaria, official programs in physical education with concrete educational content and clear instructions have been adopted. In the secondary schools in Bulgaria, Macedonia and Slovenia there are qualified specialists in physical education. Generalist teachers providing physical education classes in the primary school do not have the necessary preparation and the adequate skills for teaching physical education. There is lack of appropriate buildings and facilities for realization of the curriculum in some regions of the countries. Future activities are intended for the professional qualification in physical education and sport for generalist school teachers, and for the continuing professional development of all sports pedagogues.
\end{abstract}

Key words: school sport, learning programs, teachers, preparation, primary school

\section{Introduction}

Physical education (PE) is an integral part of the educational system. It is a compulsory subject in primary and secondary schools in the European countries. The best possibility for a positive influence on children's physical development is the well-structured and organized physical education process at schools (European Commission, Expert Group on Health-Enhancing Physical Activity, 2015). Physical development is closely linked to the promotion of health and healthy lifestyle, including lifelong physical activity and exercise (European Commission/EACEA/Eurydice, 2013). Pupils who participate in regular physical education classes have better concentration and memory, increased problem-solving abilities and positive attitude toward self and others. This improves their personal and social behavior, school climate and reduces violence and vandalism (European Commission/ EACEA/Eurydice, 2013). Physical education can "contribute crucially to the personal growth of young people in helping them to develop physical awareness and belief in their own physical abilities, along with a general feeling of bodily well-being and thus greater self-confidence and self-esteem" (http://ec.europa.eu/transparency/regexpert/).

According to the World-wide Survey of School Physical Education (UNESCO, 2014) physical education is an obligatory school subject for boys and girls in $98 \%$ of the European countries. Formally accepted national curricula are evident in $94 \%$ of countries in Europe (a proportion similarly identified in the 2010-2011 EUPEA Physical Education Survey). In the European physical education curriculum, time allocations during the primary school phase amount to an average 109 minutes weekly (range of 30-290 minutes). In the secondary school phase there is an average of 105 minutes weekly (range of 30-240 minutes) (UNESCO, 2014).

In the EU Work Plan for Sport 2014-2017 (European Commission, Expert Group on Health-Enhancing Physical Activity, 2015) it is emphasized that physical education teachers are key agents for putting physical and sport policies into practice. They 
have the most important role for the realization of different sports activities and forming of healthy life style of children. Physical education teachers should be role models and should be physically active as well. The Recommendation 13 of this document clearly states that qualified PE teachers should be preferred at all educational levels.

In secondary education a Master's degree is usually required for the positions of physical education teachers. It is pointed out that in the European Union, both generalist teachers and specialized (with a Bachelors or Masters Degrees) teachers give physical education classes. At pre-school and at primary education level, schools usually pursue a single-teacher model, where non-specialist teachers are allowed to teach physical education. In such cases, it is considered beneficial, that at least a qualified physical education teacher is provided as mentor and support to the generalist teachers.

The importance of continuous professional development (CPD) is also highlighted in this document. It is pointed that CPD should be normally available to physical education teachers, thereby facilitating interaction with other disciplines. High quality training opportunities should always be ensured to allow physical education teachers to expand their knowledge in relevant themes, such as new motor skills and sports, and health-enhancing physical activity, in order to improve the quality of their provision. Initial physical education teacher qualification should be constantly adapted to include such relevant topics, and also results from recent research and new learning approaches.

\section{Aim and objectives of the study}

the aim of the study is to compare the state and development of the school physical education in three Balkan countries - Bulgaria, Macedonia and Slovenia. The main elements of the physical education system are of special interest for the research. The following criteria are outlined: the status of $\mathrm{PE}$ in the educational system; PE learning programs; the professional qualification of teachers in PE; buildings and facilities for teaching $\mathrm{PE}$ at school.

It is important to compare the similarities and differences in the physical education systems of the three countries, and observe to what extend the elements of their systems of PE are aligned with the European requirements. Recommendations for a future development in the research are also to be given. The present study is a continuation of other comparative reports on the development of physical education in Bulgaria, Macedonia and Slovenia (Klincarov et al., 2017).

\section{Methodology}

The research methods that have been used are a study of educational documentation, an analysis of specialized literature sources, and a comparative analysis. The main documents on the current state and on the development of school physical education in Europe and world-wide have also been studied. The national strategies and documents for the system of physical education in the countries have been analyzed. The learning programs in physical education for different education levels have been discussed.

\section{Results}

In Bulgaria, a National strategy for the development of physical education and sport 2012-2022 has been adopted (http://mpes.government.bg/Documents/Documents/Strategii/Strategia_2012-2022. pdf). This strategy is a basic document of the government about the role and the social functions of physical education and sports in the Republic of Bulgaria. It reflects the need for a qualitative reorganization of the system of physical education and sport as a compulsory component of the political, economic and social changes in society.

In Slovenia the revised expert doctrine of $\mathrm{PE}$ is described in the Guidelines of Physical Education (Kristan et al., 1992). In addition to the well-established PE in schools, the development of school sport is based also on the National Program of Sport (Jurak et al., 2011). This strategic document defines the key features of Slovenian sport development for the coming decade and emphasizes the intertwining of qualitative regular compulsory $\mathrm{PE}$, school sport and out-of-school sports activities directed to as many school children as possible (Jurak et al., 2011).

The physical and health education in Macedonia is regulated by the Conception for the nine-year compulsory education (Bureau for development of education, 2007) and Law for primary education (Ministry of education and sciences of Republic of Macedonia, 2007). These two institutions, The Bureau for Development of Education and Ministry of 
Development of education are the two main state bodies responsible for all educational policies, including the strategy for physical and health education (PHE) and PHE curricula.

In the three studied countries physical education is an obligatory school subject in all levels of the educational system. In Bulgaria, it is practiced three times per week from $1^{\text {st }}$ to $12^{\text {th }}$ grade and in Macedonia, it is done three times per week from $1^{\text {st }}$ to $9^{\text {th }}$ grade. In Bulgaria the third PE lesson is provided usually as module education out of PE classes. In some schools in the country, the third PE lesson is not provided (Peneva, Buyuklieva, 2016).

In Slovenia in the first six years of schooling, children have three PE lessons per week. In grades $6^{\text {th }}-$ $9^{\text {th }}$ (end of primary school) they have two obligatory PE lessons per week, but pupils can also choose one lesson per week as an optional sport subject, out of three one-year programs (sport for health, sport for enjoyment, optional sport), and one lesson per week of an optional subject in dancing activities (Starc, Strel, 2012).

In Bulgaria, official programs in PE have been adopted, with concrete educational content and clear instructions (www.mon.bg). In 2015 and 2016 new learning programs in PE for $1^{\text {st, }} 2^{\text {nd, }} 5^{\text {th }}$ and $6^{\text {th }}$ grade was introduced (according to the new Law for School and Pre-school Education). The PE programs for $3^{\text {rd }}$ and $4^{\text {th }}$ grade and for the other educational levels are being reorganized at present. There is obligatory and elective sports content in the PE programs for school education in Bulgaria (www. mon.bg). With reference to the elective sports content, teachers can choose between different sports disciplines. It is agreed with the school principals and it depends on the facilities and the equipment of the school, and the characteristics of the region.

In Macedonia, the PE curriculum has not been changed since 2007. It is characterized with the lack of clearly defined learning objectives, no comprehensible instructions for learning across the curriculum, as well as, lack of supporting documents (Klincarov et al., 2017).

PE in Slovenian schools is based on open curriculums (Jurak et al., 2011). They include goals with recommended activities, standards of knowledge (skills and theoretical knowledge) and didactic recommendations. They evidence the connection between PE and school sport programs. In their annual working plan each school defines the course of lessons for all subjects and all additional activities, including sport activities. Schools themselves are responsible for the realization of their working plan and the programs are funded by the state and local budgets. Heterogeneous sport programs for children and youth are also offered by private enterprises.

In the secondary schools in Bulgaria, Macedonia and Slovenia there are qualified specialists in physical education. In all schools in Bulgaria from $5^{\text {th }}$ to $12^{\text {th }}$ grade, $\mathrm{PE}$ teachers are specialists, who have graduated the National Sports Academy (Peneva, Mileva, 2005), or specialized in Physical Education at the Pedagogical Faculties of the Universities in Veliko Tarnovo, Blagoevgrad, Shumen, Plovdiv and Sofia.

In most schools in Bulgaria from $1^{\text {st }}$ to $4^{\text {th }}$ grade, physical education and sports lessons are taught by generalist teachers who do not have the necessary professional qualifications and training in PE. In a small part of the big schools in the large towns in Bulgaria, all classes from $1^{\text {st }}$ to $4^{\text {th }}$ grade are conducted by certified PE specialist teachers.

The Faculty of Sport of the University of Ljubljana, is currently the only higher education institution in Slovenia for PE teachers. The course of study is five years. The three Faculties of Education (in Ljubljana, Maribor and Koper/Capodistria) educate only generalist teachers who teach PE in the primary-school classes (1 to 5). Their study program lasts four years.

The Faculty of Physical Education, Sport and Health in Skopje is the leading institution in Republic of Macedonia in education of specialized PE teachers that deliver physical and health education from $6^{\text {th }}$ to $9^{\text {th }}$ grade. The generalist teachers that teach PHE in the first stage of primary education $\left(1^{\text {st }}\right.$ to $5^{\text {th }}$ grade) are educated at the Teaching Faculties at the Universities in Skopje, Stip and Bitola, as well as at the Institute of Pedagogy at the Faculty of Philosophy in Skopje and Tetovo. The study programs at all named institutions lasts four years.

\section{Discussion}

the national strategic documents for the develop- 
ment of physical education and sport in Bulgaria, Slovenia and Macedonia outline the main approaches and the theoretical formulations, defining the strategic objectives and directions of the national systems for physical education and sport and the basic principles on which they are built. The gap between the theoretical formulations in certain parts of the documents and their practical implementation can be considered as a major drawback. From the analysis of the literature sources, it is clear that the number of PE lessons per week and the time allocation for the subject of physical education in Bulgaria, Slovenia and Macedonia meet the requirements for quality physical education. Additional optional sport and health programs or elective sports contents in primary and secondary education are available in all three countries.

Regarded the PE curriculum, recent changes are made in the PE curriculum in Bulgaria. New state educational standards for physical education at all levels of the education system are adopted. They are introduced with the new School and Pre-school Education Law (2016). In Macedonia there are no clearly defined standards for evaluation, there are only expected goals. The lack of standards is one of the major problems. The recent and current changes in the legislation of sport and PE in Bulgaria and Slovenia, are good examples which could be implemented in Macedonia, where an inappropriate construction of the national PE curriculum is observed.

One of the important observations of the research analysis is that the specialist physical education teachers in the three countries have the necessary preparation and the adequate knowledge and skills for teaching physical education. The main education level requirements for PE teachers are a Bachelor's or a Master's degree of training. At the same time, the generalist teachers providing PE classes in the primary school do not have sufficient special skills and qualification to conduct physical education lessons. The competencies of generalist teachers are much lower.

It has been observed that the schools in some regions of Bulgaria and Macedonia lack appropriate buildings and facilities for the realization of the PE curriculum (Peneva, Buyuklieva, 2016). As a result, quite often two classes in PE have to be conducted simultaneously in one and the same school gym
(Popeska, 2016). This is one of the reasons for the lack of quality physical education at primary and secondary school levels in both countries.

Future activities are aimed at higher professional qualification in physical education and sport of generalist teachers and continuing professional development of all PE teachers. Receiving a higher educational degree (a Master's Degree) is necessary. Teachers feel the greatest need for improvement of competencies which are directly applicable within PE classes. For older teachers it is important to meet some new requirements in $\mathrm{PE}$ teaching, such as the integration of students with special educational needs within regular classes, the concept of cross curricular teaching, multicultural education, etc. (Tul et al., 2015). For that purpose, some universities in Bulgaria have opened departments for professional development and training of $\mathrm{PE}$ teachers (Kl. Ohridsky Sofia University, Trakia University, Stara Zagora, and University of Shumen). In 2016 a department for continuing professional development of PE teachers was also created at the National Sports Academy in Sofia. It was aligned with the new Law for School and Pre-school Education and the new regulations for the professional qualification of teachers, adopted in January 2017. Since January 2017 many qualification courses have been organized at the National Sports Academy. They are directed at the new tendencies, methods and content of physical education in Europe and on national level.

We recommend common educational programs to be organized in the future between Bulgaria, Slovenia and Macedonia for the professional development of specialized PE teachers, for international discussions, seminars and joint projects focused on sharing positive experience between authorities, experts and pedagogues. We hope that similar initiatives will improve the quality of $\mathrm{PE}$ in all three countries.

\section{References}

Bureau for development of education. (2007), Physical and health education curriculum for first-ninth grade in nine-year primary education, Skopje: Macedonian ministry of education.

EU Work Plan for Sport 2014-2017. (2015), Expert Group on Health- enhancing physical activity, European Commission.

European Commission/EACEA/Eurydice. (2013), Physical Education and Sport at School in Europe. Eurydice 
Report. Luxembourg: Publications Office of the European Union.

Jurak, G., Kovač, M., and Strel, J. (2011c), Influence of the Enhanced Physical Education Curriculum on the Physical Fitness of Children. Croatian Journal of Education, 13(4), pp. 41-59, pp. 60-70.

Klincarov I., Popeska, B., Kovac, M., Mileva, E. and Starc, G. (2017), Comparative study on the state and the status of primary physical education in Macedonia, Slovenia and Bulgaria, in Changes in Childhood and Adolescence: Current Challenges for Physical Education, Proceedings of the 12th FIEP European Congress, 2017, Logos Verlag, Berlin, pp. 89-90.

Kristan, S., Cankar, A., Kovač, M. and Praček, T. (1992), Orientations of Physical Education at Schools. Ljubljana: Board of Education and Sport.

Ministry of education and sciences of Republic of Macedonia. (2007), Conception for nine years' compulsory primary education.

Natsionalna strategiya za razvitie na fizicheskoto vaspitanie i sporta V Republika Bulgaria 2012-2022, (Национална стратегия за развитие на физическото възпитание и спорта в Република България 20122022) available at: http://mpes.government.bg/Documents/Documents/Strategii/Strategia_2012-2022.pdf (accessed at 10 April 2017).

Peneva, B., Buyuklieva, A. (2016), Challenges in front of the profession teacher of physical education, Physical Education, Sport, Kinesitherapy Research Journal, 1(2), Art.12, pp. 58-61.

Peneva, B., Mileva, E. (2005), Social problems of Bulgarian School Physical Education (historical view), FIEP Bulletin, Vol. 75, 1, pp. 69-72.

Popeska, B. (2016), Possibilities of the classroom for re- alization of physical and health education, in Proceeding book of scientific professional summit "The teacher and the environment for learning and development", 02.10.2015, Stip: Faculty of Educational Sciences, Goce Delcev University, pp. 83-91.

Quality Physical Education (QPE). Guidelines for Policy-Makers. (2015), United Nations Educational, Scientific and Cultural Organization, available at: http:// unesdoc.unesco.org/images/0023/002311/231101E.pdf (accessed 15 March 2017).

Starc, G., Strel, J. (2012), Influence of the quality implementation of a physical education curriculum on the physical development and physical fitness of children. BMC public health, Vol. 12.

Tul, M., Leskosek, B., Jurak, G. and Kovac, M. (2015), Perceived importance of Slovenian physical education teachers' professional competencies. Hacettepe Egitim Dergisi, Vol. 30, Issue 1, pp. 268-281.

Uchebni programi po fizichesko vaspitanie i sport (Учебни програми по физическо възпитание и спорт), available at: www.mon.bg (accessed 10 April 2017).

World-wide Survey on School Physical Education, Final report 2013, UNESCO, 2014.

\section{Contact information:}

Prof. Eleonora Mileva, D. Sc., Ph.D.

Lecturer at Department of Psychology, Pedagogy and Sociology

National Sports Academy "V. Levski"

Studentski Grad, 1710 Sofia, Bulgaria

Tel.: + 359898776676

E-mail:emileva2002@yahoo.com; 